\title{
NMDA Receptor Activation in Differentiating Cerebellar Cell Cultures Regulates the Expression of a New POU Gene, Cns-1
}

\author{
Robert F. Bulleit, Hong Cui, Jiancheng Wang, and Xi Lin \\ Department of Pharmacology, University of Maryland School of Medicine, Baltimore, Maryland 21201
}

\begin{abstract}
$\mathrm{POU} /$ homeobox genes encode transcription regulatory proteins that are important in defining cellular phenotypes. Expression of these genes may be critical for to the regulation of CNS cellular differentiation. We have identified a cDNA corresponding to a new member of the POU/homeobox gene family. Expression of RNA encoded by this new gene occurs predominantly in the CNS. Thus, this new gene was designated Cns-1. Cns-1 transcripts are expressed in differentiating cells cultured from the early postnatal cerebellum. Treatment of these cultured cells with NMDA results in an increase in the level of Cns-1 RNA. This increase is blocked by simultaneous treatment with the specific NMDA receptor antagonist amino-5-phosphonovaleric acid. Continued activation of the NMDA receptor allows maintenance of this new steady state level of Cns-1 mRNA for at least $5 \mathrm{~d}$ in these cultured cells. A transcription runoff assay suggests that this increase in the level of RNA is due, at least in part, to an increase in transcription from the Cns-1 gene. The NMDA-induced increase in Cns-1 mRNA was reduced by pretreatment with calcium chelators EGTA or 1,2-bis(2-aminophenoxy)ethane- $N, N, N, N$-tetraacetic acid (BAPTA) tetrakis(acetoxymethyl). These studies suggest that specific activation of the NMDA receptor in cultures of differentiating cerebellar cells increases $C_{n s-1}$ gene expression and that calcium entry through the NMDA channel may be required for this response. This change in Cns-1 expression may modify phenotypic characteristics of these cultured cells.

[Key words: NMDA receptor, CNS development, RNA, gene expression, POU gene, cerebellar cell culture]
\end{abstract}

The mammalian CNS contains a precisely integrated network of many distinct cellular phenotypes. During CNS development these diverse cell types arise from multipotent precursor cells present in the neural tube. Clonal analysis of CNS precursors suggests that, even up to their final cell division, an individual precursor can give rise to multiple cell types (Turner and Cepko, 1987; Luskin et al., 1988; Wetts and Fraser, 1988; Walsh and Cepko, 1992). It is likely that the specification of individual cell

Received Apr. 5, 1993; revised Aug. 20, 1993; accepted Aug. 26, 1993.

We thank A. L. Joyner for providing the $E n-2 \mathrm{cDNA}$, W. Herr for providing the Oct-1 cDNA, and D. R. Burt for providing the mouse brain $\lambda \mathrm{gt} 10 \mathrm{cDNA}$ library. We thank P. Yarowsky, D. Burt, and B. Krueger for helpful comments on the manuscript. This work was supported by National Institutes of Health grant NS29792 to R.F.B. and the Frank C. Bressler Fund of the University of Maryland.

Correspondence should be addressed to Dr. Robert F. Bulleit, Department of Pharmacology, University of Maryland School of Medicine, 655 West Baltimore Street, RM 4-018, Baltimore, MD 21201.

Copyright (C) 1994 Society for Neuroscience $0270-6474 / 94 / 141584-12 \$ 05.00 / 0$ fates requires local interactions involving environmental signals (Kessler, 1986; Adler and Hatlee, 1989; Iacovitti et al., 1989; McConnell and Kaznowski, 1991). These instructive signals direct the expression of specific genes that are ultimately responsible for defining particular cell fates. Homeobox genes may be important components in this process. These genes encode transcription regulatory proteins that are likely to function in combination with other transcription factors to specify individual CNS cellular phenotypes (He and Rosenfeld, 1991). Homeobox genes have been well characterized in invertebrates, where their protein products function as key regulators of transcription involved in controlling development and defining cellular phenotypes (Akam, 1987; Scott and Carroll, 1987; Doe et al., 1988a,b; Finney et al., 1988; Ingham, 1988; Way and Chalfie, 1989). In mammals, the expression of homeobox genes occurs in both CNS precursors and mature CNS cell populations. The Hox genes (Kessel and Gruss, 1990), several POU/homeobox genes (He et al., 1989), Pax-3 (Goulding et al., 1991), Tes-1 (Porteus et al., 1991), and $N k x-2.2$ (Price et al., 1992) are expressed in cells within spatially restricted regions of the developing neural tube. In the adult nervous system Hox 1.3 and the POU/homeobox genes Brn-1, Brn-2, Tst-1, Oct-1, and Oct-2 are expressed in distinct but overlapping populations of mature CNS cells (Odenwald et al., 1987; He et al., 1989). This distinct distribution of gene expression suggests that homeobox genes may also regulate the differentiation of individual mammalian CNS cellular phenotypes.

In the developing CNS instructive signals may define individual cellular phenotypes through control of the expression of particular homeobox genes. Cells cultured from the early postnatal cerebellum may provide a useful system for studying the effect of instructive signals on the differentiation of an individual CNS neuronal phenotype. These postnatal ccrcbellar cultures contain cerebellar granule neurons and their precursors, other cerebellar interneurons, and cerebellar glia (Trenkner, 1991). Some aspects of the development and differentiation of granule neurons occur in these postnatal cerebellar cultures and can be modified by the addition of extracellular factors (Balázs et al., 1988a; Hatten et al., 1988; Kingsbury et al., 1989; Messer, 1989; Gao et al., 1991; Trenkner, 1991). We are interested in learning whether conditions that modify differentiation of these cells also alter expression of identified homeobox genes. Several studies report that activation of NMDA receptors in cultured cerebellar granule neurons can modify neurite outgrowth (Pearce et al., 1987; Cambray-Deakin and Burgoyne, 1992), survival (Balázs et al., 1988a,b), differentiation (Moran and Patel, 1989; Cox et al., 1990), and migration (Komuro and Rakic, 1992) of these cells. NMDA receptor activation also appears to mediate trophic 
responses in other CNS neurons and may rcgulate activity-dependent development of certain populations of CNS neurons (Kleinschmidt et al., 1987; I ipton and Kater, 1989; Scherer and Udin, 1989; Cline and Constantine-Paton, 1990; Kalb and Hockfield, 1990; Cline, 1991; Simon et al., 1992). Studies have also shown that spontaneously active NMDA receptors are present in the early developing CNS (Blanton et al., 1990; Lo Turco et al., 1991; Kalbet al., 1992). One mechanism by which NMDA receptor activation could control these developmental events is through the regulation of expression of particular homeobox genes.

In the present study we have identified a new member of the POU/homeobox gene family, Cns-1. Cns-1 is expressed in cells cultured from the early postnatal cerebellum. Activation of NMDA receptors in these cultured cells results in a specific increase in the level of $C n s-1$ mRNA. An increase in the level of transcription from the $C n s-1$ gene appears, at least in part, responsible for this increase in the level of $C n s-1$ mRNA. These experiments suggest that NMDA receptor activation in developing cells of the CNS can alter homeobox gene expression. This change in homeobox gene expression may ultimately modify the phenotypic properties of these cells.

\section{Materials and Methods}

Identification of POU/homeobox sequences by PCR. Total RNA was prepared from adult mouse cerebella using previously described methods (Chomczynski and Sacchi, 1987). PolyA ${ }^{+}$RNA was isolated by chromatography on oligo-dT cellulose as described by Sambrook et al. (1989). We synthesized the first strand of cDNAs using polyA ${ }^{+}$RNA primed with random hexamers and Moloney murine leukemia virus reverse transcriptase (U.S. Biochemicals, Cleveland, OH). Amplification by the polymerase chain reaction (PCR) was accomplished by the addition of polymerase buffer $(50 \mathrm{~mm} \mathrm{KCl}, 20 \mathrm{~mm}$ Tris pH 8.4, $2.5 \mathrm{~mm}$ $\mathrm{MgCl}_{2}$, and $100 \mu \mathrm{g} / \mathrm{ml} \mathrm{BSA}$ ), dNTPs, primers, and Taq DNA polymerase (U.S. Biochemicals) to the cDNA. The cycling progression involved denaturation for $2 \mathrm{~min}$ at $94^{\circ} \mathrm{C}$, primer annealing for $2 \mathrm{~min}$ at $58^{\circ} \mathrm{C}$, and primer extension for $3 \mathrm{~min}$ at $72^{\circ} \mathrm{C}$. We repeated this cycling progression 35 times with the last $72^{\circ} \mathrm{C}$ incubation lasting $15 \mathrm{~min}$. The primers used for $\mathrm{PCR}$ were degenerate oligonucleotides representing all possible codons for two regions of conserved amino acid sequence in eight POU/homeodomain proteins (He et al., 1989). The upstream primer was from a conserved region in the POU-B domain, T/S-T-I$\mathrm{C} / \mathrm{S}-\mathrm{R}-\mathrm{F}-\mathrm{E}$, and the downstream primer was from a conserved region in the homeodomain, V-I/V-R-V-W-F-C-N (see Fig. 2). We had the upstream primer synthesized with a $5^{\prime}$ EcoRI restriction site and the downstream primer with a $5^{\prime}$ Xbal restriction site. Following PCR amplification DNA products were separated on a $1 \%$ agarose gel and stained with ethidium bromide. The DNA bands migrating to a position corresponding to $320-350$ base pairs (bp) (expected sizc of POU/homeobox sequences based on the position of the primers) were purified as a single pool. We digested this DNA with EcoRI and XbaI, and ligated into the EcoRI-XbaI sites of the pGEM7Z vector. This DNA was used to transform Escherichia coli. Individual clones were isolated and the plasmid DNA purified for DNA sequence analysis (Sanger et al., 1977).

Isolation of Cns-1 $c D N A s$. We synthesized a random-primed DNA probe from the PCR clone PCRPH3. This probe was used to screen an amplified adult $\mathrm{C} 57 \mathrm{Bl} / 6 \mathrm{~J}$ mouse brain $\lambda \mathrm{gt} 10 \mathrm{cDNA}$ library (obtained from D. R. Burt, University of Maryland School of Medicine). We transferred $6 \times 10^{5}$ recombinants from this library to nitrocellulose filters by standard procedures (Sambrook et al., 1989). Filters were prehybridized for $2-4 \mathrm{hr}$ at $42^{\circ} \mathrm{C}$ in $\mathrm{H}$ buffer containing $5.6 \times$ SSPE $\left(0.84 \mathrm{M} \mathrm{NaCl}, 64 \mathrm{~mm} \mathrm{Na}_{2} \mathrm{PO}_{4}, 6 \mathrm{~mm}\right.$ EDTA), $50 \%$ formamide, $5 \times$ Denhardt's solution $(0.1 \%$ ficoll, $0.1 \%$ polyvinylpyrrolidone, $0.1 \%$ bovine serum albumin), $1 \%$ SDS, and $200 \mu \mathrm{g} / \mathrm{ml}$ tRNA. We preformed hybridizations in $\mathrm{H}$ buffer containing $1-3 \times 10^{6} \mathrm{cpm} / \mathrm{ml}$ of PCRPH3 probe (specific activity of $1-2 \times 10^{\circ} \mathrm{cpm} / \mu \mathrm{g}$ ) for $48 \mathrm{hr}$ at $42^{\circ} \mathrm{C}$. Filters were washed under high-stringency conditions $[0.1 \times \mathrm{SSC}(15 \mathrm{~mm} \mathrm{NaCl}$, $1.5 \mathrm{~mm}$ sodium citrate), $1 \% \mathrm{SDS}$ at $\left.65^{\circ} \mathrm{C}\right]$ and exposed to Kodak RP $\mathrm{x}$-ray film. We purified 10 positive clones and determined the cDNA insert size by restriction enzyme analysis. The longest clone (PH3,1-2) contained an insert of $\sim 4.6$ kilobases $(\mathrm{kb})$. The insert was subcloned into the plasmid pBluescript (Stratagene, La Jolla, CA) for restriction mapping and sequence analysis. We generated subclones for sequence analysis by restriction enzyme and exonuclease III digestion (Henikoff, 1984). We used double-stranded plasmid DNA for sequence analysis of both DNA strands (Sanger et al., 1977). The GenBank accession number for the Cns-1 cDNA sequence is L13763.

Cell cultures from the early postnatal cerebellum. Cells from the cerebellum of postnatal day 7 (P7) CD-1 mice were dissociated into a single-cell suspension by previously described methods (Kingsbury et al., 1989); 1-2 $\times 10^{7}$ cells were plated on $35 \mathrm{~mm}$ petri dishes in a chcmically defined medium composed of minimal essential medium (without glutamic acid and glycine) containing $6 \mathrm{mg} / \mathrm{ml}$ glucose, $10 \mu \mathrm{g} /$ $\mathrm{ml}$ bovine serum albumin (Sigma, St. Louis, MO), $200 \mu \mathrm{g} / \mathrm{ml}$ human transferrin (Sigma), $32 \mu \mathrm{g} / \mathrm{ml}$ putrescine (Sigma), $10 \mathrm{ng} / \mathrm{ml}$ sodium selenite (Sigma), $10 \mu \mathrm{g} / \mathrm{ml}$ insulin (Sigma), $1.25 \mathrm{ng} / \mathrm{ml}$ progesterone (Sig$\mathrm{ma}$ ), $20 \mathrm{ng} / \mathrm{ml}$ triiodothyronine (Sigma), $4 \mathrm{ng} / \mathrm{ml}$ corticosterone (Sigma), $2 \mathrm{~mm}$ glutamine (Sigma), and $100 \mu \mathrm{g} / \mathrm{ml}$ gentamicin (GlBCO/Bethesda Research Labs, Gaithersburg, MD). This medium allows extended survival of cultured neurons without NMDA or depolarizing concentrations of $\mathrm{KCl}$ (Cox et al., 1990). The cultures were maintained for $24 \mathrm{hr}$ at $37^{\circ} \mathrm{C}$ in $5 \% \mathrm{CO}_{2}$. Under these conditions the cells formed large aggregates with bundles of interconnecting cell processes similar to cerebellar cultures describes previously (Trenkner, 1991). After $24 \mathrm{hr}$ of culture we added $\mathrm{KCl}$ to each culture to bring the final concentration to $10 \mathrm{mM}$. Cultures were then treated with $10 \mu \mathrm{M}$ glycine (Sigma), 20 $\mu \mathrm{M}$ 6-cyano-7-nitroquinoxaline-2,3-dione (CNQX; Cambridge Research Biochemicals), $100 \mu \mathrm{M}$ amino-5-phosphonovaleric acid (APV; Sigma), $0.1-200 \mu \mathrm{M} N$-methyl-D-aspartate (NMDA; Sigma), $10 \mu \mathrm{M}$ $\gamma$-aminobutyric acid (GABA; Sigma), $10 \mu \mathrm{M}$ somatostatin (Calbiochem, San Diego, CA), and/or basic fibroblast growth factor (Calbiochem). We added these compounds directly to the culture medium. Incubation of cultures was continued for $0-24 \mathrm{hr}$ at $37^{\circ} \mathrm{C}$ in $5 \% \mathrm{CO}_{2}$. We treated some cultures containing $10 \mathrm{mM} \mathrm{KCl}$ and $10 \mu \mathrm{M}$ glycine for $2 \mathrm{hr}$ with 4 or $8 \mathrm{mM} \mathrm{MgSO}_{4}, 1.5$ or $2.5 \mathrm{~mm}$ ethylene glycol-bis( $\beta$-aminoethyl ether) $N, N, N^{\prime}, N^{\prime}$,-tetraacetic acid (EGTA; Sigma) or $20 \mu \mathrm{M} 1,2$-bis(2-aminophenoxy)ethane- $N, N, N^{\prime}, N^{\prime}$-tetraacetic acid (BAPTA) tetrakis(acetoxymethyl) ester (Molecular Probes, Eugene, OR). We added NMDA $(50 \mu \mathrm{M})$ directly to the culture medium following pretreatment of cells with $\mathrm{Mg}^{2+}$ or EGTA. After BAPTA pretreatment we removed the BAPTA-containing medium from cells and replaced with the fresh chemically defined medium, minus BAPTA, containing $50 \mu \mathrm{m}$ NMDA. These cultures were then incubated for an additional $24 \mathrm{hr}$. The viability of cultured cells following these various treatment conditions was determined by trypan blue exclusion. Cells are loosely attach to the petri dish and can be removed and dissociated by trituration through a pipette tip. After dissociation, cell viability was determine by incubating cells in $0.08 \%$ trypan blue in PBS. Cells that excluded the dye and those that incorporated the dye were counted using a hemocytometer. Viability was expressed as the percentage of total cells that excluded the dye.

$R N A$ hlot analysis. We prepared total RNA from adult mouse tissues or from cultured cells using previously described methods (Chomczynski and Sacchi, 1987). We separated total RNA $(20 \mu \mathrm{g})$ from individual adult tissues or cultured cells by formaldehyde agarose gel electrophoresis (Sambrook et al., 1989). The gels were stained with ethidium bromide and the RNA visualized under UV light to confirm that similar amounts of RNA were loaded in each lane of the gel. We transferred the RNA to nylon membranes (Stratagene, La Jolla, CA) by standard capillary transfer (Sambrook et al., 1989). RNA was cross-linked to membranes using a UV cross-linker (Stratagene, La Jolla, CA). We hybridized RNA blots with a cDNA probe synthesized by random priming from a $3.7 \mathrm{~kb}$ EcoRI-HindIII fragment of PH3,1-2. RNA blots were prehybridized for $2-4 \mathrm{hr}$ at $42^{\circ} \mathrm{C}$ in $\mathrm{H}$ buffer (as described above). Hybridization was accomplished in $\mathrm{H}$ buffer containing $1-3 \times 10^{6} \mathrm{cpm} /$ $\mathrm{ml}$ of probe (specific activity of $1-2 \times 10^{9} \mathrm{cpm} / \mu \mathrm{g}$ ) for $48-72 \mathrm{hr}$ at $42^{\circ} \mathrm{C}$. Blots were washed under high-stringency conditions $(0.1 \times \mathrm{SSC}, 1 \%$ $\mathrm{SDS}$ at $65^{\circ} \mathrm{C}$ ) and exposed to Kodak AR x-ray film for $1-3 \mathrm{~d}$. After $\mathrm{x}$-ray film exposure the probe was removed from blots by incubation in 25 mM Tris $\mathrm{pH} 7.5,0.5 \times$ Denhardt's $(0.01 \%$ ficoll, $0.01 \%$ polyvinylpyrrolidone, $0.01 \% \mathrm{BSA}$ ), $0.1 \%$ SDS for $30 \mathrm{~min}$ at $85^{\circ} \mathrm{C}$. We hybridized the same blots under conditions described above with a probc synthcsized from a $3 \mathrm{~kb}$ EcoRI fragment of an $E n-2 \mathrm{cDNA}$ obtained from A. L. Joyner, Mt. Sinai Hospital Research Institute, University of Toronto. Probes synthesized from other cDNAs were also used to rehybridize blots:, an Oct-1 cDNA was obtained from W. Herr, Cold Spring Harbor 
294 Lys Leu Asn Val Phe Gln Ile Pro

917 AAG CTG AAC GTC TTT CAG ATC CCG TAG GGC TCA GTG TCA GCG TGT GCC GGC GCA

Met Pro Gly Ile Ser C ACT ACA GCT CCA GTT ATT ACC AAC ACC ATT CCC AGC ATG CCC GGG ATC AGC

Ser Gln Ile Leu Thr Asn Ala Gln Gly Gln Val Ile Gly Ala Leu Pro Trp Val AGT CAG ATC CTC ACG AAT GCT CAG GGA CAG GTT ATT GGA GCA CTT CCG TGG GTA

Val Asn Ser Ala Ser Val Ala Thr Pro Ala Pro Ala Gln Ser Leu Gin Val Gln GTG AAC TCA GCT AGC GTG GCC ACA CCA GCA CCG GCA CAG AGC CTG CAG GTC CAA

Ala Val Thr Pro Gln Leu Leu Leu Asn Ala Gln Gly Gln Val Ile Ala Thr Leu GCC GTG ACT CCC CAG CTC TTG TTG AAT GCC CAG GGC CAG GTG ATC GCA ACC CTA Ala ser Ser Pro Leu Pro Gin Pro Val Ala Val Arg Lys Pro Asn Thr pro Glu GCC AGC AGC CCC CTG CCT CAG CCT GTG GCT GTC AGG AAG CCA AAC ACA CCG GAG

Ser Pro Ala Lys Ser Glu Val Gln Pro Ile Gln Pro Thr Gin Ala Val pro Gln TCC CCT GCT AAG AGT GAG GTG CAG CCT ATC CAG CCG ACA CAA GCC GTG CCC CAG

Pro Ala Val Ile Leu Thr Ser Pro Thr Pro Ala Leu Lys Pro Ser Ala Ala Thr CCT GCA GTA ATC CTC ACC AGC CCA ACG CCA GCG CTC AAG CCG TCA GCT GCA ACT Pro Ile Pro Ile Thr Cys Ser Glu Thr Pro Thr Val Ser Gln Leu Val Ser Lys CCC ATC CCA ATC ACC TGC TCA GAG ACC CCA ACC GTC AGT CAG TTG GTA TCA AAG Pro His Thr Pro Ser Leu Asp Glu Asp Gly Ile Asn Leu Glu Glu Ile Arg Glu CCG CAC ACC CCA AGT CTG GAT GAG GAC GGG ATC AAC TTA GAA GAG ATC CGG GAG Phe Ala Lys Asn Phe Lys Ile Arg Arg Leu Ser Leu Gly Leu Thr Gin Thr Gin TTT GCT AAG AAT TTT AAG ATC CGG CGG CTC TCC CTG GGT CTG ACA CAG ACC CAG Val Gly Gin Ala Leu Thr Ala Thr Glu Gly Pro Ala Tyr ser Gln Ser Ala Ile GTG GGC CAG GCT TTG ACG GCG ACA GAA GGG CCG GCC TAC AGC CAA TCA GCC ATC Cys Arg Phe Glu Lys Leu Asp Ile Thr Pro Lys Ser Ala Gln Lys Leu Lys Pro TGC AGG TTT GAG AAA TTG GAC ATC ACA CCC AAG AGC GCC CAG AAG CTG AAG CCG Val Leu Glu Lys Trp Leu Met Glu Ala Glu Leu Arg Asn Gln Glu Gly Gln GIn GTT TTG GAA AAG TGG TTG ATG GAG GCA GAG CTC CGC AAC CAG GAA GGC CAG CAG

Asn Leu Met Glu phe Val Gly Gly Glu Pro Ser Lys Lys Arg Lys Arg Arg Thr AAC CTG ATG GAG TTC GTG GGC GGC GAG CCC TCC AAG AAA CGC AAG CGG CGC ACT

Ser Phe Thr Pro Gln Ala Ile Glu Ala Leu Asn Ala Tyr Phe Glu Lys Asn Pro TCC TTC ACA CCG CAG GCC ATA GAG GCT CTC AAT GCC TAC TTT GAG AAA AAC CCC Leu Pro Thr Gly Gln Glu Ile Thr Glu Ile Ala Lys Glu Leu Asn Tyr Asp Arg CTG CCC ACC GGC CAG GAG ATC ACG GAG ATC GCC AAG GAG CTC AAC TAC GAC CGG Glu Val Val Arg Val Trp Phe Cys Asn Arg Arg GIn Thr Leu Lys Asn Thr Ser GAG GTG GTG AGG GTC TGG TTC TGT AAT CGA CGC CAG ACA CTG AAG AAC ACC AGC

Figure 1. Part of the nucleotide sequence of the Cns- 1 cDNA is presented along with the predicted amino acid sequence of the Cns- 1 protein. The open reading frame begins with an ATG that is consistent with Kozak's criteria for an initiation codon (Kozak, 1986, 1991). The predicted amino acid sequence of Cns-1 contains a POU-specific domain, a homeodomain, and a domain rich in serine, threonine, and proline residues. These domains are shown by the boxed sequences. The GenBank accession number for the Cns- 1 cDNA sequence is L13763.

Laboratory; SCIP/Tst- 1 and Cer-1 CDNAs were isolated in our laboratory (R. F. Bulleit, unpublished observations). Repeated stripping of probes from blots reduced subsequent hybridization signals so that film exposure times frequently increased and varied from 2 to $12 \mathrm{~d}$. Each experiment using cultured cells was repeated at least two times and the results of RNA blot analysis were consistently replicated in repeated experiments.

Nuclear runoff transcription assay. We measured transcriptional activity by isolating nuclei from cells $\left(\sim 3 \times 10^{7}\right.$ cells $)$ cultured in the presence or absence of $50 \mu \mathrm{M}$ NMDA or $100 \mu \mathrm{M}$ APV. Cells were lysed in $10 \mathrm{~mm}$ Tris- $\mathrm{HCl} \mathrm{pH} 7.4,10 \mathrm{mM} \mathrm{NaCl}, 3 \mathrm{~mm} \mathrm{MgCl}, 5 \% \mathrm{NP} 40$, and nuclei were prepared as previously described (Greenbery and Ziff, 1984). In vitro nuclear transcription was carried out in the presence of ribonucleotides and ${ }^{32} \mathrm{P}-\mathrm{UTP}$ at $30^{\circ} \mathrm{C}$ for $30 \mathrm{~min}$ (Greenberg and Ziff, 1984). We isolated labeled KNA by methods described previously (Groudine et al., 1981). Labeled transcripts produced in this manner were hybridized in $6 \times$ SSC, $5 \times$ Denhardt's, $1 \%$ SDS, $200 \mu \mathrm{g} / \mathrm{ml}$ tRNA at $65^{\circ} \mathrm{C}$ for $36-48 \mathrm{hr}$ to DNA immobilized on nitrocellulose filters. We hybridized each filter with an equal number of cpm and washed filters under stringent conditions $\left(0.1 \times \mathrm{SSC}, 1 \%\right.$ SDS at $\left.65^{\circ} \mathrm{C}\right)$. The filters were exposed to Kodak AR x-ray film for $5 \mathrm{~d}$. Nitrocellulose filters were prepared using plasmid DNA $(10 \mu \mathrm{g})$ linearized by restriction digestion and de- 
$\mathrm{POU}_{\underline{\mathrm{g}}^{-A}} \mathrm{POU}_{\underline{\mathrm{g}}}-\mathrm{B}$

\section{III}

pit-1

cfla

brn-1

brn-4

tst-1

ceh-6

Iv

unc-86

1-pou

$$
6 \text { RQ }
$$

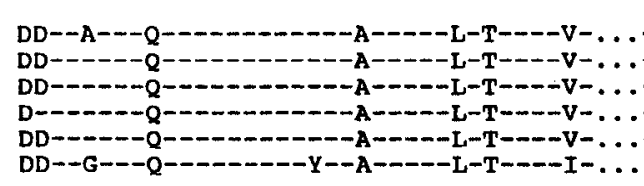

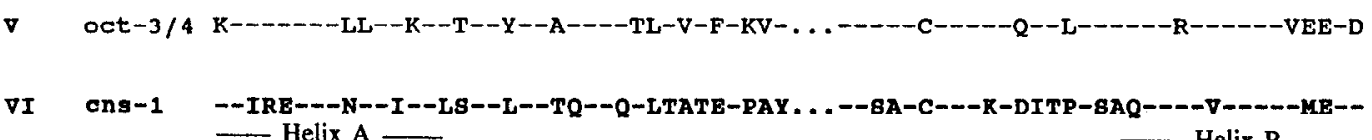

LINKER

NLSSDSSLSSPSALNSPGI EGLS. TMSVDSSLPSPNQLSSPSLGFEPA

QVGALYNEKVGANE.........

SSTGSPTSIDKIAAQ . . . . . STTGSPTSIDKIAAQ ....... SSSGSPTSIDKIAAQ ........ SSTGSPTSIDKIAAQ ........ SSSGSPTNLDKIAAR........ STTGSPNSTFEKMTGQA......

EAMKOKDTIGDINGILPNT . . . . . GPQREKMNKPELFNG.......... AQAKNKRRDPDAPSVLPA.....

NNENLQEICKSETLVQA. . . . .

LRNQEGQQNLMEFVGGEPS . . . . .

\section{HOMEODOMATN}

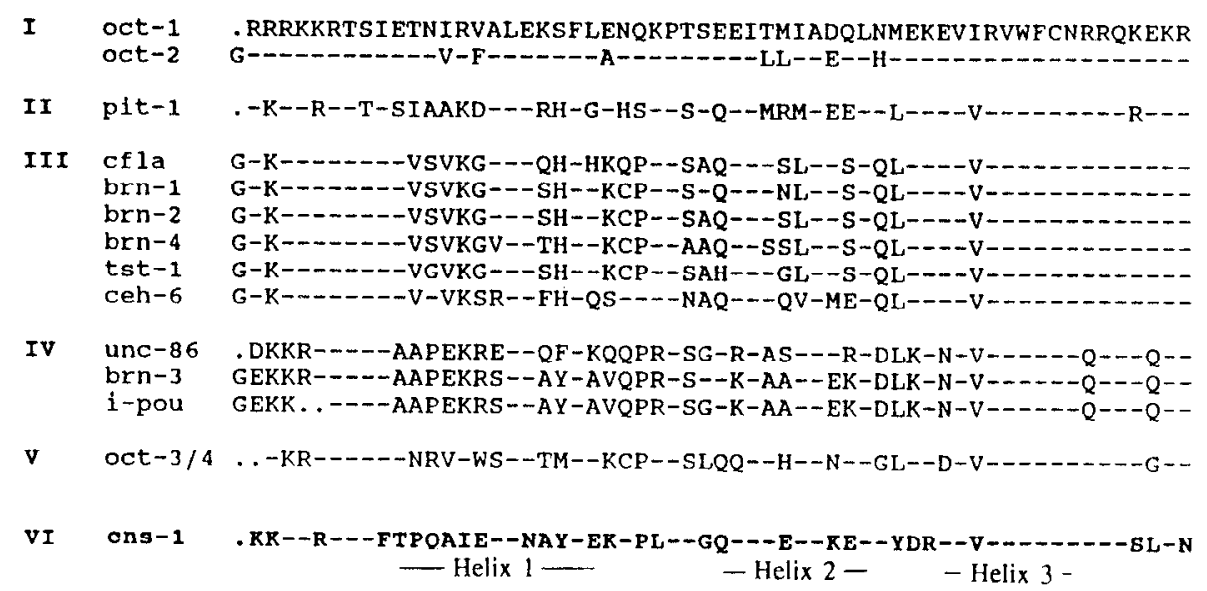

Figure 2. The predicted amino acid sequence of Cns-1 is similar to other POU/homeodomain proteins in the POU-specific domain and the homeodomain. All amino acid sequence information except that for Brn-4 and Cns-1 was as reported by Rosenfeld (1991) The amino acid sequence for Brn-4 was as reported by Le Moine and Young (1992). The amino acid sequence for Cns- 1 is as reported in this publication. The sequences are grouped into six classes based on relative sequence similarity. A dash indicates identity of amino acid sequence with Oct-1. The solid black bars identify the position of the sequences used in designing PCR primers. Regions with $\alpha$-helical structure are indicated as Helix $A$ and Helix $B$ in the POU-specific domain and Helix 1,2 , and 3 in the homeodomain.

natured in $0.2 \mathrm{M} \mathrm{NaOH}$ for $30 \mathrm{~min}$ at room temperature followed by neutralization in 10 vol of $6 \times \mathrm{SSC}$. We immobilized the DNA on nitrocellulose filters using a slot blot apparatus (Bio-Rad, Richmond, CA). Filters were baked for $2 \mathrm{hr}$ at $80^{\circ} \mathrm{C}$. The plasmid DNAs used in these experiments included a plasmid containing a $3.7 \mathrm{~kb}$ fragment of the $C n s-1$ cDNA, a plasmid containing a $3 \mathrm{~kb}$ fragment of the $E n-2$ cDNA, and a control plasmid, pGEM11Z.

Densitometry. Densitometry (Molecular Dynamics densitometer, Sunnyvale, $\mathrm{CA}$ ) of exposed $\mathrm{x}$-ray films was used to quantitate the hybridization signals on RNA blots hybridized with $C n s-1$ and $E n-2$ probes and in nuclear runoff transcription assays. Densitometric measurements (optical density, OD) were made on autoradiographs of RNA blots from three separate experiments in which cells were treated with glutamate receptor agonists of antagonists (see Fig. 4) or from threc scparatc nuclear runoff transcription experiments (see Fig. 9). Background OD values were determined on each blot and subtracted from OD values for $C n s-1$ and $E n-2$ hybridization signals. We recorded the mean $O D$ values \pm standard error of the mean for both $C n s-1$ and $E n-2$ hybridization signals in RNA from cells treated under different conditions. Statistical analysis of the difference between the mean OD values for different treatment conditions was accomplished using a $t$ test. We observed that the level of the hybridization signal for $E n-2$ RNA didn't significantly change with any of the treatment conditions and was directly proportional to the level of $28 \mathrm{~S}$ and $18 \mathrm{~S}$ RNAs as visualized by ethidium staining of the RNA gels. Thus, $E n-2$ can provide a reasonable measure of the relative amount of RNA on each blot.

\section{Results}

\section{Isolation of Cns-1 cDNA clones}

Reverse transcription of cerebellar RNA in combination with the PCR allowed identification POU/homeobox genes expressed in the cerebellum. PCR was accomplished using degenerate oligonucleotide primers representing all possible codons for two conserved regions (Fig. 2). PCR amplification yielded DNA fragments within the expected size range based on the position of the two primers. These PCR products were subcloned and individual clones were isolated and sequenced. Several different POU/homeobox cDNA clones were identified using this PCR protocol. The deduced amino acid sequence of one of these 

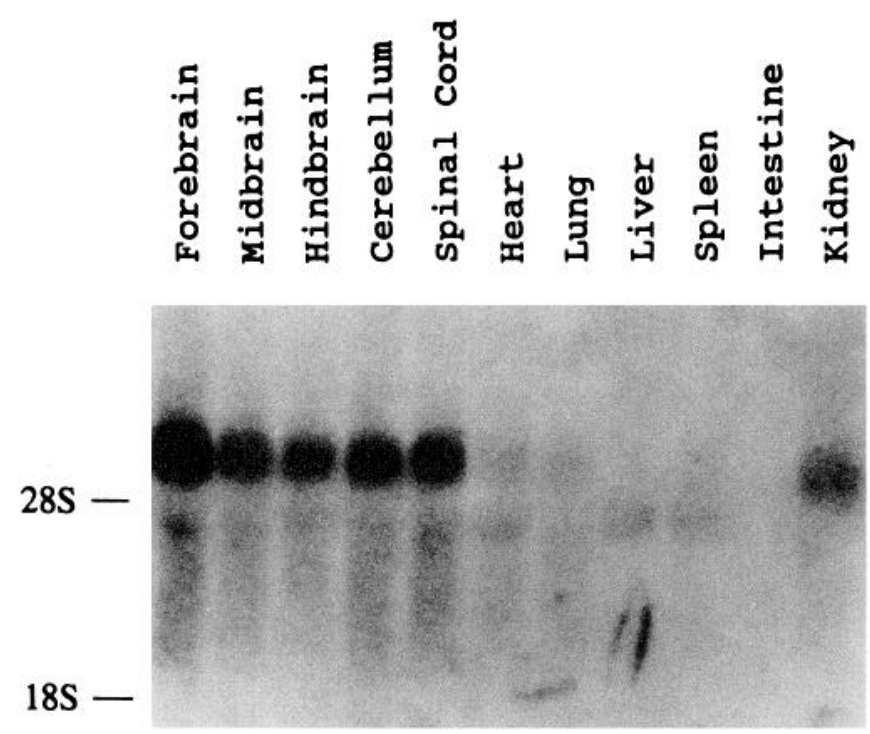

Figure 3. Cns- 1 mRNA is expressed in the adult CNS. RNA was isolated from different adult brain regions and different adult tissues. Total RNA $(20 \mu \mathrm{g})$ from each of the indicated brain regions or tissues was separated in a $1 \%$ formaldehyde agarose gel and transferred to a nylon membrane. The membrane was incubated with a random-primed DNA probe synthesized from a $3.7 \mathrm{~kb}$ fragment of the $C n s-I$ cDNA clone $\mathrm{PH} 3,1-2$. Probe hybridization and washing was accomplished as described in Materials and Methods. Following wash procedures, blots were exposed to Kodak AR x-ray film. Indicated on the left side are the positions of the $28 \mathrm{~S}$ and $18 \mathrm{~S}$ rRNAs.

clones (PCRPH3) suggested it encoded a new member of the POU/homeodomain protein family. We used a probe synthesized from the PCRPH3 clone to isolate full-length cDNAs from a mouse brain $\lambda \mathrm{gt} 10 \mathrm{cDNA}$ library. We isolated 10 clones that contained overlapping restriction maps. The largest clone ( $\mathrm{PH} 3,1-$ 2) contained an insert of $\sim 4.6 \mathrm{~kb}$. Sequence analysis of this clone revealed an open reading frame beginning with an ATG that is consistent with Kozak's criteria for an initiation codon (Kozak, 1986, 1991). The open reading frame is 903 base pairs long and encodes a 301 amino acid protein with a molecular weight of 32,850 (Fig. 1). This amino acid sequence contains regions that are similar but not identical to the POU-specific domain and the homeodomain of other POU/homeodomain proteins (Figs. 1, 2). We have designated this new sequence Cns-1.

An amino acid sequence comparison of the POU-specific domain and the homeodomain of Cns- 1 and 13 other POU/homeodomain proteins is presented in Figure 2. Cns-1 is $48-57 \%$ identical to the other POU/homeodomain proteins within the POU-specific domain and 43-52\% identical within the homeodomain. The greatest similarity was observed between Cns-1 and Pit-1, where there was $57 \%$ identity in the POU-specific domain and 52\% identity in the homeodomain. Cns- 1 and Pit-1 also have similar secondary structural features. Prediction of secondary structure in Cns-1 (Chou and Fasman, 1978) suggests that within the POU-specific domain and the homeodomain there are five $\alpha$-helical regions. In the POU-specific domain one helical domain resides in each of the POU subdomains (POU-A and POU-B) and three helical domains are present in the homeodomain (Fig. 2). The position of these helical domains is similar to the position of predicted helices in Pit-1 (Ingraham et al., 1990). We also observed that within the amino-terminal half of Cns- 1 is a region rich in serine, threonine, and proline residues (Fig. 1). This domain consists of $25 \%$ serine and threonine residues and $21 \%$ proline residues. Similar regions rich in serine and threonine residues are also present in the POU/ homeodomain proteins Pit-1 and Oct-2 (Ingraham et al., 1990; Tanaka and Herr, 1990).

\section{Cns- 1 is expressed in the CNS}

We examined the tissue distribution of Cns-1 mRNA. Total RNA was isolated from different adult brain regions and other tissues. We did RNA blot analysis under high-stringency conditions using a DNA probe synthesized from the Cns-1 cDNA clone $\mathrm{PH} 3,1-2$. Under these conditions the probe hybridized to an $\sim 5 \mathrm{~kb}$ transcript (Fig. 3). This transcript was present in all regions of the CNS examined (forebrain, midbrain, hindbrain, cerebellum, and spinal cord). We also observed hybridization to RNA of the same size in RNA isolated from kidney tissue. We detected only faint hybridization signals in the other tissues examined (heart, lung, liver, spleen, and intestine). Thus, Cns- 1 mRNA is expressed predominantly although not exclusively in the CNS. We have also observed that Cns- 1 RNA is expressed in the developing postnatal cerebellum (P1-P21; data not shown). A comprehensive evaluation of the developmental expression of $C n s-1$ in the CNS is currently under way.

\section{Expression of Cns-1 is modulated by activation of NMDA receptors in cells cultured from the early postnatal cerebellum}

Cultured established from the early postnatal cerebellum contain cerebellar granule cells and their precursors, other cerebellar interneurons, and cerebellar glia (Trenkner, 1991). Cells were cultured at high density in a chemically defined medium that allows extended survival of these cells without depolarizing concentrations of $\mathrm{KCl}$ (Cox et al., 1990). We cultured cells for 24 $\mathrm{hr}$ before the addition of glutamate receptor agonists and/or antagonists. RNA blot analysis shows that $C n s-1 \mathrm{mRNA}$ is expressed in cultures under all treatment conditions (Fig. 4A). The $C n s-1$ probe hybridized to two different-sized transcripts (Fig. 4A). The smaller of the two RNAs was the same size as the prominent $C n s-1$ transcript observed in adult tissues (Fig. 3). This larger RNA was also observed in adult tissues if blots were exposed for longer periods of time (data not shown). Since all of the RNA blots were washed at high stringency, this larger RNA must be a transcript from a very closely related gene, a splicing variant of the $C n s-1$ transcript or derived from the use of an alternate polyadenylation signal. An RNase protection experiment suggested that RNA from cultured cells could fully protect a 300 bp RNA fragment synthesized from the Cns- I cDNA. We observed no other partially protected fragments (data not shown). This observation suggests that the observed transcripts on RNA blots are likely to be derived from the Cns-1 gene. However, further studies are necessary to determine which of several possibilities might account for the larger transcript.

The level of these Cns-1 mRNAs changed in response to treatment with NMDA receptor agonists and antagonists. Treatment of cultures with glycine $(10 \mu \mathrm{M})$, which potentiates agonist response at the NMDA receptor (Johnson and Ascher, 1987), or $20 \mu \mathrm{M}$ CNQX, a non-NMDA glutamate receptor antagonist, did not result in a significant difference in the level of Cns-1 RNA when compared to control cultures (Fig. 4A, lanes 1-3). Treatment with $100 \mu \mathrm{M} \mathrm{APV}$, a competitive antagonist at the NMDA receptor, appeared to reduced the level of Cns- 1 RNA when compared to treatment with $10 \mathrm{~mm} \mathrm{KCl}$ (Fig. $4 A$, lane 
A
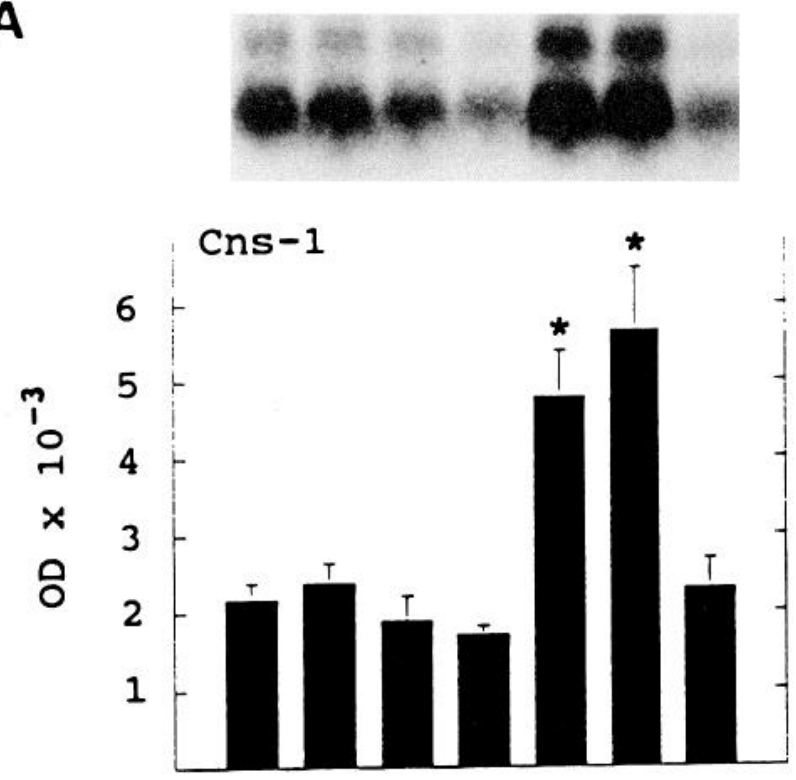

B

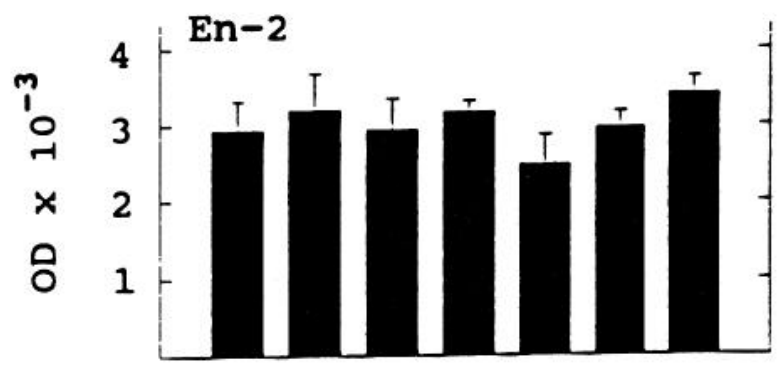

$10 \mathrm{mM} \mathrm{KCl}$

$10 \mu \mathrm{M} \mathrm{GlY}$

$20 \mu \mathrm{M}$ CNQX $100 \mu \mathrm{M}$ APV $50 \mu \mathrm{M}$ NMDA
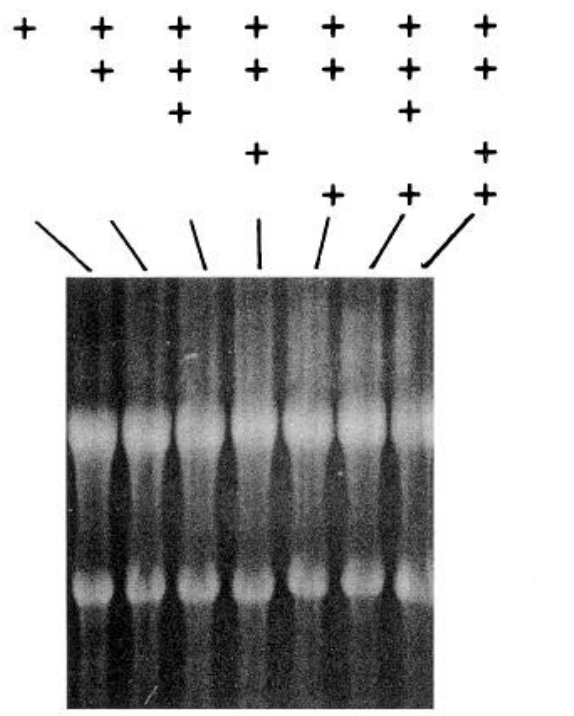

Figure 4. NMDA receptor activation increases the expression of Cns-1 mRNA in cultured cerebellar cells. Cells from the early postnatal cerebellum were cultured for $24 \mathrm{hr}$ in a chemically defined medium containing $5 \mathrm{~mm} \mathrm{KCl}$. Cultures were continued for an additional $24 \mathrm{hr}$ in medium containing $(+) 10 \mathrm{~mm}$ potassium chloride $(\mathrm{KCl}), 10 \mu \mathrm{M}$ glycine (Gly), $20 \mu \mathrm{M}$ 6-cyano-7-nitroquinoxaline-2,3-dione (CNQX), $100 \mu \mathrm{M}$ amino-5-phosphonovaleric acid (APV), and/or $50 \mu \mathrm{M} N$-methyl-D-as-
4). However, this difference was not statistically significant when averaging the results from three separate experiments (Fig. 4A). Alternatively, treatment of cultures with $50 \mu \mathrm{M}$ NMDA resulted in a significant increase in the level of $C n s-1$ mRNA (Fig. $4 A$, lane 5). Simultaneous addition of APV to cells treated with NMDA blocked the NMDA induced increase in the level of Cns- 1 mRNA (Fig. 4 $A$, lane 7). However, CNQX did not affect this increase (Fig. $4 A$, lane 6). A comparison of the mean OD measurements from blots of three separate experiments showed that treatment of cells with NMDA or NMDA plus CNQX resulted in a 2.8-3.3-fold increase in the level of Cns-1 mRNA when compared to APV-treated cultures and a 2.2-2.6-fold increase when compared to control cultures. These differences were statistically significant at $p$ values $<0.03$. We observed a similar increase in the level of the larger Cns-1 transcript following NMDA treatment. Treatment of these cultures with 20 $\mu \mathrm{M}$ glutamate also resulted in an increase in the level of $\mathrm{Cns}-1$ mRNA that was blocked by cotreatment with APV (data not shown). We remove the Cns-1 probe from the blots and rehybridized the blots with a probe to the homeobox gene $E n-2$ to determine if the levels of other homeobox gene transcripts were also increase in response to NMDA treatment. Densitometric measurements of the $E n-2$ hybridization signals showed that there was no significant change in the level of $E n-2$ RNA following treatment with any of NMDA receptor agonists or antagonists (Fig. $4 B$ ). Thus, NMDA treatment does not result in a general increase in the level of all homeobox gene transcripts. We also observed that the changes in the level of En-2 RNA were consistent with changes in the level of RNAs as measured by absorbance at $260 \mathrm{~nm}$ and visualization by ethidium staining of the RNA gels (Fig. $4 C$ ). Thus, the $E n-2$ hybridization signal provides a measure of the relative amount of RNA in each lane of the blot and suggests that the increase in Cns- $I$ mRNA is not the result of differences in the level of total RNA on the blots. Examination of RNAs encoded by several other homeobox genes suggested that the levels of mRNA for these genes were, for the most part, not altered by treatment with NMDA (Fig. 5). RNAs encoding En-2, the POU/homeobox gene Oct1 , and a newly identified homeobox gene related to the Drosophila paired gene, Cer-1 (Bulleit, unpublished observations), are expressed at similar levels under all treatment conditions (Fig. 5). The exception was RNA encoded by the POU/homeobox gene SCIP (Monuki et al., 1989; also referred to as Tst-1 or $O c t-6$ ), which also appeared to increase in response to NMDA treatment, but to a lesser degree than Cns-1 mRNA. Thus, NMDA receptor activation specifically results in an increase in transcripts for the $C n s-1$ gene and possibly the SCIP/Tst-1 gene.

NMDA caused a dose-dependent increase in the level of the Cns-1 mRNA. We observed a response at concentrations of

$\leftarrow$

partate $(N M D A) . A$, RNA blot analysis using an $C n s-1$ cDNA probe was accomplished as described in Figure 3 and Materials and Methods. The mean $\mathrm{OD} \pm \mathrm{SE}$ from densitometric measurements of the autoradiographs of three separate blots is presented along with a representative autoradiographic image. The asterisks $\left({ }^{*}\right)$ indicate that these mean OD values are statistically different $(P<0.03)$ than the mean OD values for any of the other treatment conditions. $B$, The $C n s-1$ probe was removed from the blots and the blots were hybridized with an En-2 cDNA probe (refer to Materials and Methods). The mean OD \pm SE of the hybridization signals is presented along with the autoradiographic image from the same blot presented in $A$. $C$, Ethidium bromide staining of the RNA gel used for blot analysis to obtain the autoradiographic image presented in $A$ and $B$. 


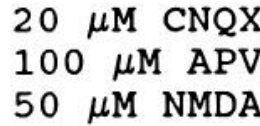

$50 \mu \mathrm{M}$ NMDA

Cns-1

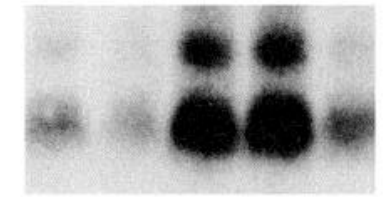

SCIP/Tst-1

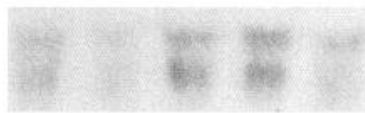

oct-1

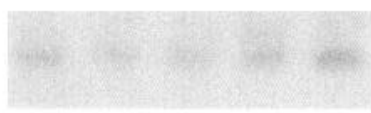

En-2

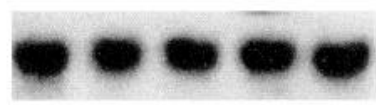

Cer-1

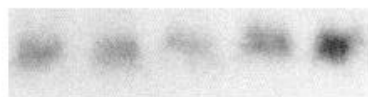

Figure 5. NMDA receptor activation does not affect the expression of several homeobox gene transcripts in cultured cerebellar cells. Cells from the early postnatal cerebellum were cultured for $24 \mathrm{hr}$ in a chemically defined medium containing $5 \mathrm{mM} \mathrm{KCl}$. Cultures were continued for an additional $24 \mathrm{hr}$ in medium containing $10 \mathrm{~mm} \mathrm{KCl}$ and $10 \mu \mathrm{M}$ glycine plus (+) $20 \mu \mathrm{M}$ 6-cyano-7-nitroquinoxaline-2,3-dione (CNQX), $100 \mu \mathrm{M}$ amino-5-phosphonovaleric acid $(A P V)$, and/or $50 \mu \mathrm{m} \mathrm{N}$-methyl-D-aspartate $(N M D A)$. RNA blot analysis using an $C n s-1$ cDNA probe was accomplished as described in Figure 3 and Materials and Methods. Probes to several other homeobox genes $(E n-2, O c t-1, S C I P / T s t-1$, and Cer-1) were used for repeated rehybridization to the same blot (refer to Materials and Methods).

NMDA as low as $10 \mu \mathrm{M}$, reaching a peak at 50-100 $\mu \mathrm{M}$ NMDA (Fig. 6A). The increase was also apparent in cells treated with NMDA in physiologic magnesium $(5 \mathrm{~mm})$ without added glycine (Fig. 7). High concentrations of $\mathrm{KCl}(40 \mathrm{~mm})$ also resulted in an increase in Cns- 1 transcript levels (Fig. 7). Treatment of cells with GABA, somatostatin, or basic fibroblast growth factor did not affect the level of Cns-1 RNA (Fig. 7) although cultured granule cells express functional receptors for all three of these ligands (Hatten et al., 1988; Bovolin et al., 1992; Gonzalez et al., 1992). An increase in the level of this mRNA was first apparent $\sim 2 \mathrm{hr}$ after the start of NMDA treatment (Fig. $6 B$ ). The level of mRNA continued to increase up to $24 \mathrm{hr}$ following NMDA treatment (Fig. $6 B$ ). This increase in the level of $C n s-1$ mRNA could be maintained for at least $5 \mathrm{~d}$ (Fig. 8). APV added after $4 \mathrm{~d}$ of NMDA treatment reduced the level of $C n s-1$ mRNA to control levels over the next $24 \mathrm{hr}$ of culture (Fig. 8). The above data suggest that the specific activation of the NMDA receptor results in an increase in the level of $C n s-1$ mRNA and that the maintenance of this increased mRNA level requires that this receptor remain active.

The results of experiments described above suggest that activation of NMDA receptors in cultures of early postnatal cerebellar cells result in a specific increase in the level of Cns- 1
A

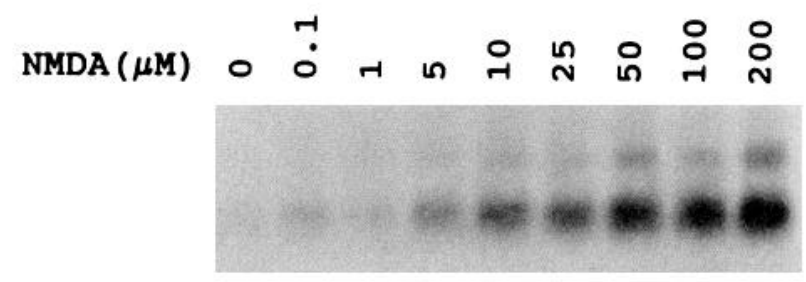

B

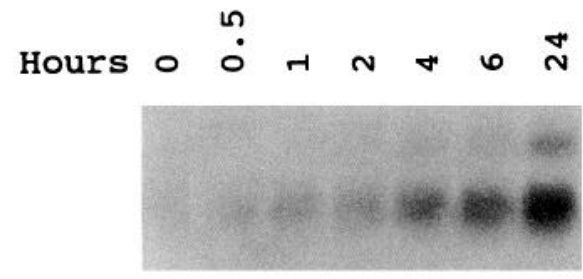

Figure 6. NMDA receptor activation regulates the expression of Cns- 1 mRNA in a concentration- and time-dependent manner. Cells from the early postnatal cerebellum were cultured in a chemically defined medium containing $5 \mathrm{~mm} \mathrm{KCl}$. $A$, Cultures were continued for an additional $24 \mathrm{hr}$ in medium containing $10 \mathrm{~mm} \mathrm{KCl}$ and $10 \mu \mathrm{M}$ glycine plus $0-200$ $\mu \mathrm{M} N$-methyl-D-aspartate $(N M D A) . B$, Cultures were continued for additional time $(0-24 \mathrm{hr})$ in medium containing $10 \mathrm{~mm} \mathrm{KCl}$ and $10 \mu \mathrm{M}$ glycine plus $50 \mu \mathrm{m}$ NMDA. RNA blot analysis using an Cns-1 cDNA probe was accomplished as described in Figure 3 and Materials and Methods.

mRNA. This increase in the steady state mRNA level could be the result of an increase in transcript synthesis or a decrease in transcript degradation. We measured the level of transcript synthesis using isolated nuclei from cultured cerebellar cells that had been treated with either APV or NMDA. A nuclear runoff transcription assay was used to measure the level of transcription from both the Cns-1 and En-2 genes (Greenberg and Ziff, 1984). Nuclei isolated from cultured cells after $24 \mathrm{hr}$ of treatment with NMDA exhibited a 1.6-fold increase in transcription from the Cns-1 gene when compared to nuclei of cells treated with APV (Fig. 9). These observations suggest that the NMDA induced change in Cns- 1 mRNA level is at least in part the result of an increase in the rate of transcription from the Cns- 1 gene. However, we cannot rule out that a change in the rate of transcript degradation is also partially involved in mediating this response since the increase in the level of transcription is not identical to the increase in the level of Cns-1 RNA.

\section{Calcium mediates the increase in the level of Cns-1 RNA in response to NMDA treatment}

The NMDA receptor is a ligand-gated ion channel that when opened allows cations to move across the cell membrane, including $\mathrm{Ca}^{2+}$. At physiologic $\mathrm{Mg}^{2+}$ concentrations there is a voltage-dependent $\mathrm{Mg}^{2+}$ block of the NMDA channel (Mayer et al., 1984). Depolarizing conditions release $\mathrm{Mg}^{2+}$ from the channel allowing $\mathrm{Ca}^{2+}$ to enter the cell. High $\mathrm{Mg}^{2+}$ concentrations will antagonize NMDA receptor activation by blocking the channel. Treatment of cultured cerebellar cells with high $\mathrm{Mg}^{2+}$ concentrations $(4 \mathrm{~mm}$ ) consistently reduced the increase in Cns-1 mRNA in response to NMDA treatment (Fig. 10). Although higher concentrations of $\mathrm{Mg}^{2+}(8 \mathrm{~mm})$ didn't reduce the viability of cultured cells (Fig. 11), they did alter the mor- 


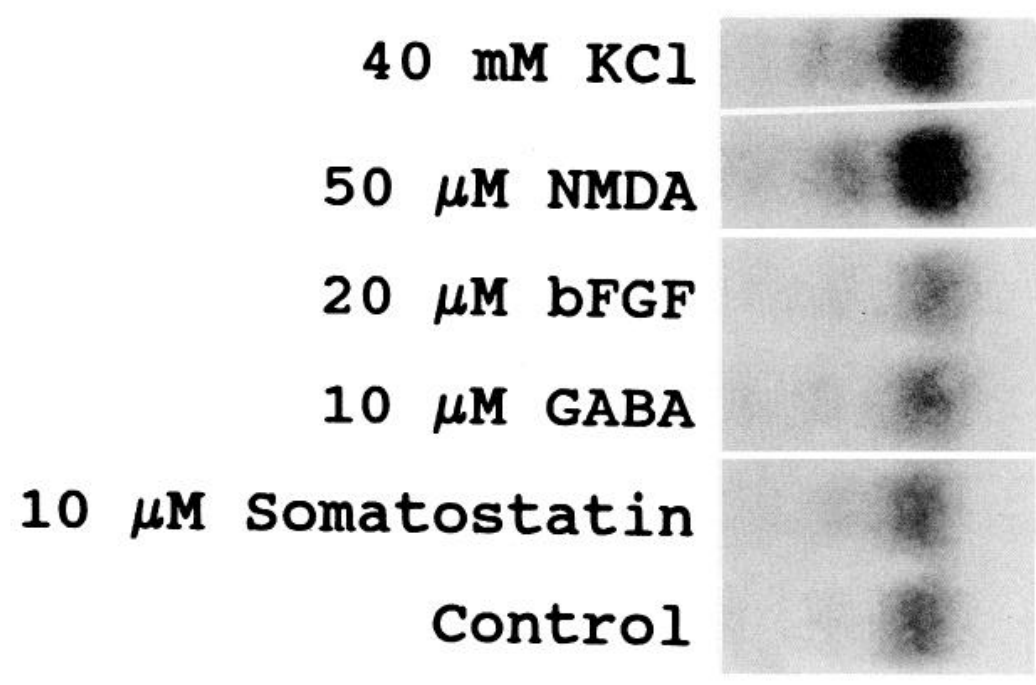

Figure 7. Treatment of cultured cerebellar cells with both NMDA and high concentrations of $\mathrm{KCl}$ results in an increase in the level of Cns- 1 mRNA. Cells from the early postnatal cerebellum were cultured for $24 \mathrm{hr}$ in a chemically defined medium containing $5 \mathrm{~mm} \mathrm{KCl}$. Cultures were continued for an additional $24 \mathrm{hr}$ in medium containing 5 mm potassium chloride $(\mathrm{KCl})$ plus 10 $\mu \mathrm{M} \gamma$-aminobutyric acid $(G A B A), 10 \mu \mathrm{M}$ somatostatin, $20 \mu \mathrm{M}$ basic fibroblast growth factor $(b F G F), 50 \mu \mathrm{M} N$-methylD-aspartate $(N M D A)$ or $40 \mathrm{~mm} \mathrm{KCl}$. RNA blot analysis using an Cns-1 cDNA probe was accomplished as described in Figure 3 and Materials and Methods.

phology of the cultures, appearing to reduce cell aggregation. Thus, we didn't use higher concentration of $\mathrm{Mg}^{2+}$ in these experiments. The incomplete block by $4 \mathrm{~mm} \mathrm{Mg}^{2+}$ may' result from a reduced sensitivity of the NMDA receptor to $\mathrm{Mg}^{2+}$ in developing neurons (Bowe and Nadler, 1990; Morrisett et al., 1990). However, the observation that $4 \mathrm{~mm} \mathrm{Mg}^{2+}$ could reduce the NMDA response suggests that an open NMDA receptor/ channel is required to induce the change in Cns- 1 transcript levels. We also used $\mathrm{Ca}^{2+}$ chelators to determine if $\mathrm{Ca}^{2+}$ entry through the NMDA channel mediates the increase in the level of Cns- 1 RNA. Treatment of cells with $1.5 \mathrm{~mm}$ EGTA, a chelator of extracellular $\mathrm{Ca}^{2+}$, reduced the NMDA mediated increase in Cns- 1 mRNA (Fig. 10). A membrane-permeant form of BAPTA (BAPTA acetoxymethyl ester) was used as an intracellular chelator of $\mathrm{Ca}^{2+}$. Cells were pretreated for $2 \mathrm{hr}$ with BAPTA and the BAPTA containing medium was removed before exposure to NMDA. Conversion of the BAPTA analog to the parent acid occurs inside the cell sequestering it inside the cellular compartment. Treatment with these calcium chelators reduced the level of $C n s-I$ mRNA in response to NMDA (Fig. 10). The level of $E n-2$ RNA was the same under all these treatment conditions (data not shown). Thus, chelation of either extracellular and intracellular calcium reduced the response of

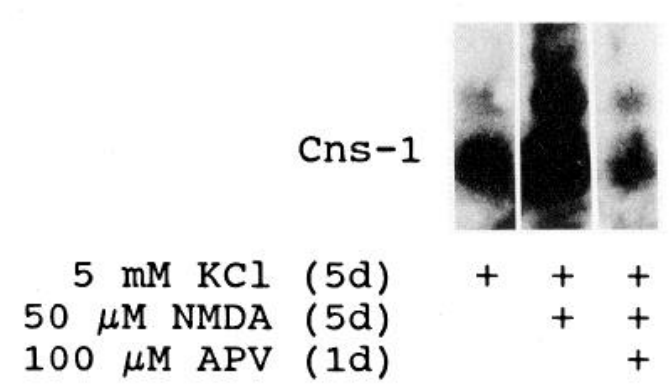

Figure 8. The maintenance of an increase in Cns- 1 mRNA is dependent on the continued activation of the NMDA receptor. Cells from the early postnatal cerebellum were cultured for $5 \mathrm{~d}$ in a chemically defined medium containing (+) $5 \mathrm{~mm}$ potassium chloride $(\mathrm{KCl}), 5 \mathrm{~mm}$ $\mathrm{KCl}$ plus $50 \mu \mathrm{M} N$-methyl-D-aspartate $(N M D A)$, or $5 \mathrm{mM} \mathrm{KCl}$ plus 50 $\mu \mathrm{M}$ NMDA in which $100 \mu \mathrm{M}$ amino-5-phosphonovaleric acid $(A P V)$ was added for the last $24 \mathrm{hr}$. RNA blot analysis using an Cns- $1 \mathrm{cDNA}$ probe was accomplished as described in Figure 3 and Materials and Methods. these cultured cells to NMDA. Only higher concentrations the chelator EGTA ( $2.5 \mathrm{~mm}$ ) reduced cell viability in these cultures (Fig. 11). All other culture treatments did not reduce cell viability when compared to control cultures (Fig. 11). Except for

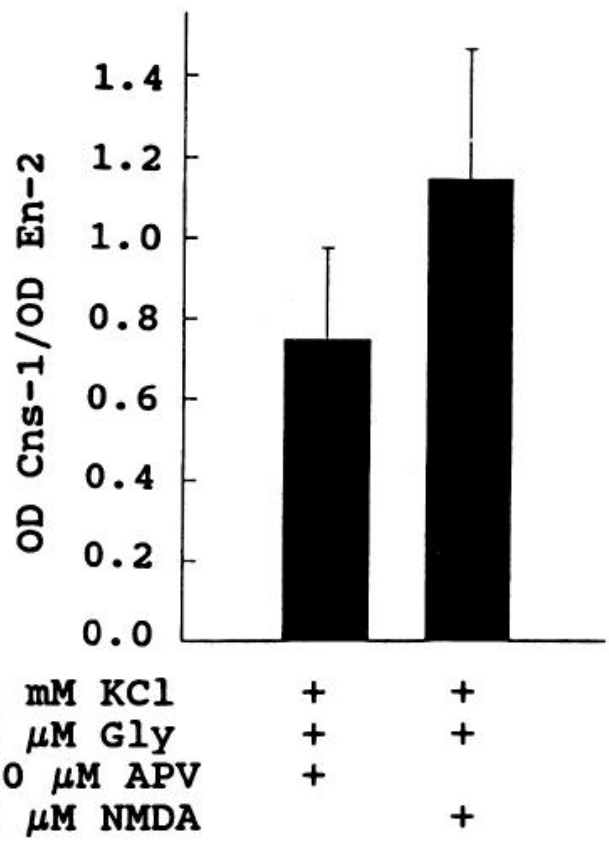

Figure 9. NMDA receptor activation increases the synthesis of transcripts from the Cns- 1 gene. Cells from the early postnatal cerebellum were cultured for $24 \mathrm{hr}$ in a chemically defined medium containing 5 m $\mathrm{KCl}$. Cultures were continued for an additional $24 \mathrm{hr}$ in medium containing $(+) 10 \mathrm{~mm}$ potassium chloride $(\mathrm{KCl})$ and $10 \mu \mathrm{M}$ glycine $(\mathrm{Gly})$ plus $100 \mu \mathrm{M}$ amino-5-phosphonovaleric acid ( $A P V)$, or $50 \mu \mathrm{M} N$-methyl$\mathrm{D}$-aspartate $(N M D A)$. Nuclei isolated from treated cells were used in a nuclear transcription runoff assay as described in Materials and Methods. RNA probes, synthesized from nuclei in vitro using ${ }^{32} \mathrm{P}$-UTP, were incubated with a $C n s-1$ cDNA, an $E n-2$ cDNA, or control plasmid DNA (pGEM 11Z) that had been immobilized to nitrocellulose membranes. Densitometric measurements $(O D)$ of probe hybridization signals were made from autoradiographs in three separate experiments. OD values for hybridization of probes to pGEM11Z DNA were used as background and subtracted from OD values for hybridization to $C n s-1$ cDNA and En-2 cDNA. The ratio of the OD measurement for $C n s-1$ to the OD measurement for $E n-2$ is presented as the mean \pm standard error. 


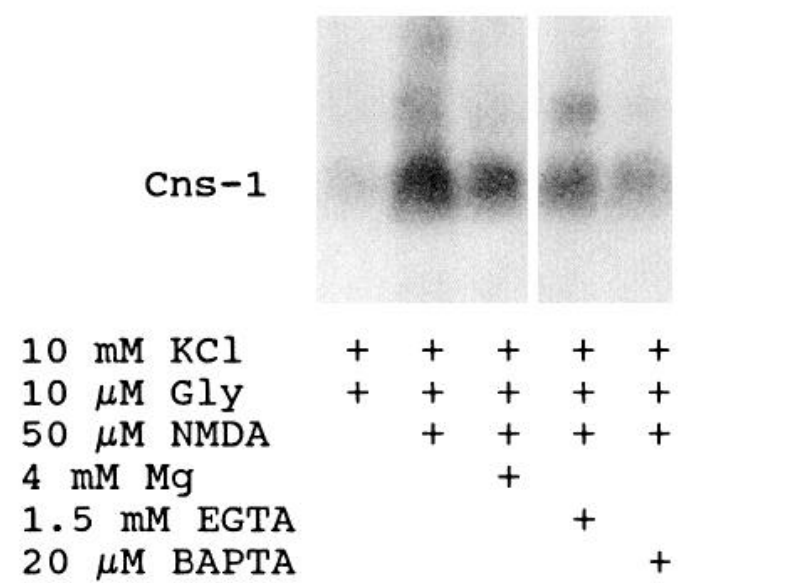

Figure 10. Calcium chelators block the increase in expression of Cns-1 mRNA in response to NMDA receptor activation. Cells from the early postnatal cerebellum were cultured for $24 \mathrm{hr}$ in a chemically defined medium containing $5 \mathrm{~mm} \mathrm{KCl}$. Cultures were continued for an additional $2 \mathrm{hr}$ in medium containing $(+) 10 \mathrm{~mm}$ potassium chloride $(\mathrm{KCl})$ and $10 \mu \mathrm{M}$ glycine (Gly) plus $4 \mathrm{~mm} \mathrm{MgSO}_{4}(M g), 1.5 \mathrm{~mm}$ ethylene glycolbis( $\beta$-aminoethyl ether) $N, N, N^{\prime}, N^{\prime}$,-tetraacetic acid $(E G T A)$, or $20 \mu \mathrm{M}$ 1,2-bis(2-aminophenoxy)ethane- $N, N, N^{\prime}, N^{\prime}$-tetraacetic acid (BAPTA) tetrakis(acetoxymethyl). Following the pretreatment with either magnesium or EGTA, $50 \mu \mathrm{M} \mathrm{N}$-methyl-D-aspartate $(N M D A)$ was added directly to the culture medium. Following BAPTA pretreatment, the BAPTA containing medium was removed and replaced with fresh medium, minus BAPTA, containing $50 \mu \mathrm{M}$ NMDA. The cultures were the incubated for an additional $24 \mathrm{hr}$. RNA blot analysis using an Cns-I cDNA probe was accomplished as described in Figure 3 and Materials and Methods.

treatment with $8 \mathrm{~mm} \mathrm{Mg}^{2+}$ and $2.5 \mathrm{~mm}$ EGTA, these treatment conditions also did not appear to affect morphology of cultures, as examined under phase-contrast microscopy. Thus, cell death induce by the treatment conditions is not likely to account for the response to NMDA or the antagonism of this response by calcium chelators.

\section{Discussion}

The amino acid sequence of Cns- 1 is similar to the sequence of other POU/homeodomain proteins in the conserved POU-specific domain and homeodomain. Relative amino acid sequence similarity between these proteins in these two conserved domains separates them into five classes (Rosenfeld, 1991). There is an $80-98 \%$ identity between members of an individual POU/ homeodomain protein class. Cns- 1 is at most $57 \%$ identical to any other POU/homeodomain protein in these two domains. Thus, Cns-1 appears to belong to a sixth and new class of POU/ homeodomain protein. The POU-specific domain and the homeodomain are involved in sequence specific DNA binding required for these proteins to function as transcriptional activators (Sturm and Herr, 1988; Ingraham et al., 1990). Outside the POU-specific domain and homeodomain, there are no conserved regions between Cns-1 and other POU/homeodomain proteins. However, Cns-1 contains a region in the amino-terminal half that is similar in amino acid composition to regions in other POU/homeodomain proteins. This region is rich in serine, threonine, and proline residues (Fig. 1). Regions with similar amino acid composition in Pit- 1 and Oct- 1 function as transcriptional activation domains (Theill et al., 1989; Ingraham et al., 1990; Tanaka and Herr, 1990). Thus, it is possible, given the sequence and structural similarity of Cns-1 with other POU/ homeodomain proteins, that Cns-1 also functions as a tran-

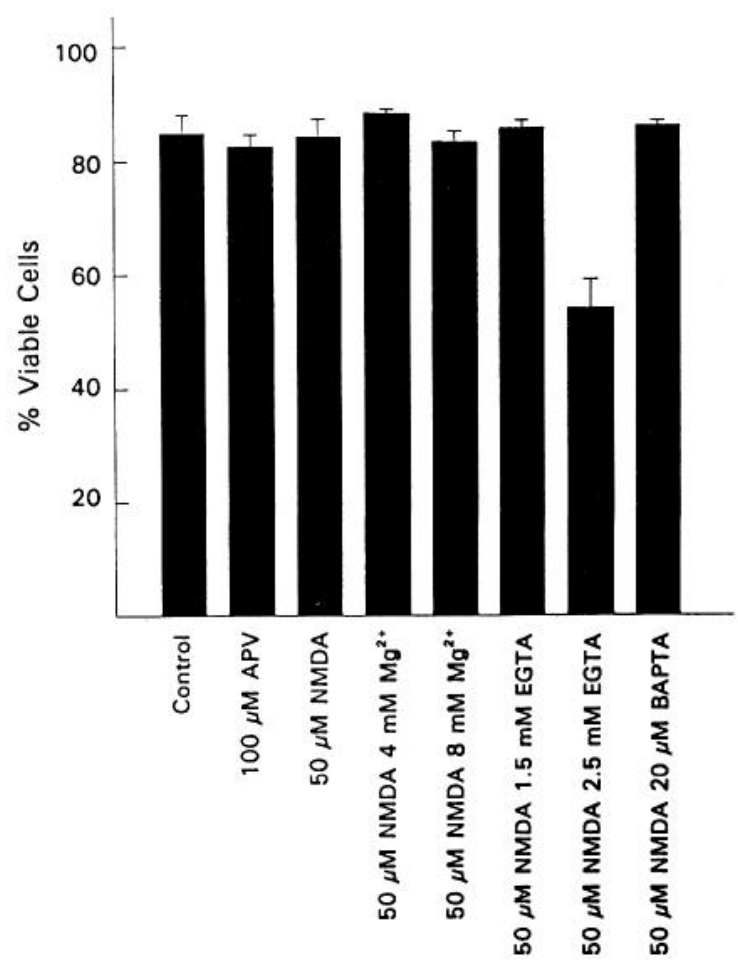

Figure 11. Viability of postnatal cerebellar cells in culture. Cells from the early postnatal cerebellum were cultured for $24 \mathrm{hr}$ in a chemically defined medium containing $5 \mathrm{~mm} \mathrm{KCl}$. Cultures were further incubated for $2 \mathrm{hr}$ in medium containing $10 \mathrm{mM} \mathrm{KCl}$ and $10 \mu \mathrm{M}$ glycine. Some cultures also contained 4 or $8 \mathrm{mM} \mathrm{MgSO}_{4}\left(\mathrm{Mg}^{2+}\right), 1.5$ or $2.5 \mathrm{~mm}$ ethylene glycol-bis $\left(\beta\right.$-aminoethyl ether) $N, N, N^{\prime}, N^{\prime}$,-tetraacetic acid $(E G T A)$, or $20 \mu_{\mathrm{M}}$ 1,2-bis(2-aminophenoxy)ethane- $N, N, N^{\prime}, N^{\prime}$-tetraacetic acid (BAPTA) tetrakis(acetoxymethyl). Except for cells treated with BAPTA, after the $2 \mathrm{hr}$ pretreatment either $50 \mu \mathrm{M} \mathrm{N}$-methyl-D-aspartate (NMDA) or $100 \mu \mathrm{M}$ amino-5-phosphonovaleric acid $(A P V)$ was added directly to the culture medium. In the case of cells pretreated with BAPTA, the BAPTA-containing medium was removed and replaced with fresh medium, minus BAPTA, containing $50 \mu \mathrm{M}$ NMDA. All cultures were the incubated for an additional $24 \mathrm{hr}$ in the presence of NMDA or APV. Cell viability was measured using a trypan blue exclusion assay described in Materials and Methods. Six separate viability measurements were done on cells treated with each condition. The mean percentage of viable cell \pm standard error is presented for each treatment condition. The viability of cell treated in 2.5 mM EGTA was significantly reduced compared to cell under any other treatment condition $(P<0.01)$.

scriptional activator. However, further studies are necessary to determine definitively whether Cns- 1 functions in this manner.

POU/homeodomain and homeodomain proteins are important transcriptional regulators involved in controlling development and determining individual cellular phenotypes (Ingham, 1988; Rosenfeld, 1991; Ruvkun and Finney, 1991). As a member of the POU/homeodomain protein family, Cns-1 may function similarly in the CNS, a tissue where it is predominantly expressed (Fig. 3). We have observed that Cns-1 is expressed in reaggregate cultures of cells derived from the early postnatal cerebellum (Fig. 4). This in vitro preparation of CNS cells consists primarily of cerebellar granule cells but also contains other cerebellar cellular phenotypes including glia (Trenkner and Sidman, 1977; Trenkner, 1991). Several aspects of cerebellar granule neuron development may occur in these reaggregate cultures, including cell division of granule neuron precursors (Gao et al., 1991), neurite extension, and granule neuron migration (Trenkner and Sidman, 1977). Cns-1 may be expressed in any of the 
cell types present in these culture and thus may be involved in determining their phenotype(s). Determination of what cell types express $C n s-1$ must come from experiments to localize its expression within individual cells.

We have made an interesting observation concerning expression of $\mathrm{Cns}-1$ in the cerebellar reaggregate cultures. Treatment of these cultures with NMDA at concentrations greater than 10 $\mu \mathrm{M}$ results in an increase in the level of Cns- $1 \mathrm{mRNA}$ that is blocked by simultaneous treatment with APV, an NMDA receptor antagonist. We did not observe antagonism of this NMDA response by CNQX, an antagonist of non-NMDA glutamate receptors (Fig. 4A). Treatment of these cultures with APV alone consistently reduced the level of Cns- $1 \mathrm{mRNA}$. Although this was not statistically significant, it is possible that an endogenous activator of the NMDA receptor is present in these cultures. Since granule neurons are glutaminergic and can release glutamate under conditions of tissue culture, it is likely that this endogenous activator is glutamate (Gallo et al., 1982; Van Vliet et al., 1989). The addition of glycine, a coagonist at the NMDA receptor, might be expected to increase the level of $C n s-1$ mRNA by potentiating the response of NMDA receptors to endogenous glutamate (Johnson and Ascher, 1987). However, we observed no significant change in the in the level of Cns-1 mRNA in response to glycine. In cerebellar slice preparations from the early postnatal cerebellum, endogenous activity of the NMDA receptor on granule neurons is absent unless glycine is present (D'Angelo et al., 1990). Our reaggregate cultures respond to NMDA at physiologic concentration of $\mathrm{KCl}(5 \mathrm{~mm})$ even without added glycine (Fig. 7). These observations suggest that endogenously release glycine may also be present in these cultures. Variability in the level of Cns-I RNA under control conditions may be the result of variability in the amount of endogenous NMDA receptor agonists present in the cultures. Thus, cultures treated with APV may provide a more accurate measure of the basal level of expression of Cns- 1 RNA. At resting membrane potentials there is a voltage-dependent $\mathrm{Mg}^{2+}$ block of the NMDA channel (Mayer et al., 1984). Activation of the channel in the presence of an agonist is dependent on depolarization of the cell that removes the $\mathrm{Mg}^{2+}$ block. At physiologic $\mathrm{K}^{+}$our cultures responded to NMDA (Figs. 7,8 ). This may be due to endogenous glutamate activating non-NMDA glutamate receptors or spontaneous depolarizing activity in the cell providing a depolarizing response to remove the $\mathrm{Mg}^{2+}$ block. Alternatively, this result may be due to a difference in the NMDA receptor's $\mathrm{Mg}^{2+}$ sensitivity in developing neurons (Bowe and Nadler, 1990; Morrisett et al., 1990). The observation that CNQX did not affect the NMDA-induced increase in $C n s$ - 1 RNA would suggest that activation of non-NMDA glutamate receptors was not involved in the response. The combined results of these pharmacologic experiments suggest that specific activation of the NMDA subtype of glutamate receptors in cultured cerebellar cells increases the level of Cns-1 mRNA. Experiments using several other homeobox genes, En-2, Oct-1, SCIP/Tst-1, and Cer-1, suggest that NMDA receptor activation has a relatively specific effect on the level of $C n s-1$ mRNA. Three of these sequences, $E n$ 2, $O c t-1$, and $S C I P / T S t-1$, have been previously shown to be expressed in the cerebellum (Davis and Joyner, 1988; Davis et al., 1988; He et al., 1989). Excepting SCIP/Tst1, NMDA receptor activation did not alter the level of mRNA encoded by these genes (Fig. 8). However, the response is not limited to the Cns- 1 since the level of $S C I P / T s t-1$ RNA also appears to increase in response to NMDA treatment.
An increase in the level of $C n s-1$ mRNA in responsc to NMDA was first apparent about 2-4 hr after NMDA treatment (Fig. $6 B$ ). The level of $C n s-1$ mRNA reached a new steady state level after about $24 \mathrm{hr}$ of NMDA treatment. This new level was maintained as long as the NMDA receptor remained active. A transcription assay also suggests that, at least in part, this increase in the level of $C n s-1$ mRNA is the result of an increase in transcription from the Cris-1 gene (Fig. 9). The timing of the response would suggest that the synthesis of new genes and their protein products may be require for new $\mathrm{Cns}-\mathrm{l}$ gene expression. The immediate-early genes may be candidates for regulators of Cns- $I$ expression. Many of these genes are transcription regulators whose expression rapidly increases in the CNS in response to a variety of signals, including NMDA receptor activation (Cole et al., 1989; Szekely et al., 1989; Morgan and Curran, 1991). Further experiments will be required to test whether this interaction takes place.

Changes in the level of expression of individual homeobox genes regulate various aspects of development and cellular differentiation (Akam, 1987; Scott and Carroll, 1987; Ingham, 1988). Similarly, the observed increase in Cns- 1 expression may mediate developmental changes of cultured cerebellar cells in response to NMDA receptor activation (Pearce et al., 1987; Balázs et al., 1988a,b; Moran and Patel, 1989; Cox et al., 1990; Cambray-Deakin and Burgoyne, 1992). This increase in Cns-1 expression may occur in granule cells that express functional NMDA receptors (Cull-Candy and Ogden, 1985; Sciancalepore et al., 1989; Cox et al., 1990), or alternatively, granule neuron activation by NMDA could secondarily modify $C n s-1$ expression in other cell types, possibly glia. If the $2.8-3.3$-fold increase in the level of Cns-1 RNA is occurring in individual cells, is this change large enough to affect cellular differentiation? In Drosophila there are several studies that suggest there is a concentration dependence of homeodomain protein function. The homeodomain protein encoded by bicoid has a critical threshold concentration necessary to activate expression of a second developmental control gene hunchback (Driever and NüssleinVolhard, 1989; Struhl et al., 1989). As little as a twofold difference in the concentration of the bicoid protein will determine whether hunchback gene expression is on or off (Struhl et al., 1989). In two loss-of-function mutants the normal two copies of the homeobox genes Ultrabithorax or Sex combed reduced are replaced by only a single copy of the gene. These mutants develop abnormally with a partial transformation of larval segments (Lewis, 1963; Kaufman et al., 1980). In Drosophila, gene dosage usually determines the concentration of the gene's producl. Thus, as little as a twofold change in the level of expression of a homeodomain protein can initiate new gene expression, modifying cellular development and differentiation. Thus, it is possible that this increase in $C n s-1 \mathrm{mRNA}$ level could also result in alterations in the differentiation of postnatal cerebellar cells in culture. However, it must first be demonstrated that the increase in Cns-1 mRNA results in a comparable increase in the Cns- 1 protein and that this increase in Cns- 1 protein corresponds to a significant change in developmental gene expression.

Both NMDA and depolarizing concentrations of $\mathrm{KCl}$ have similar effects on the development and differentiation of cerebellar cells in culture (Gallo et al., 1987; Moran and Patel, 1989; Cox et al., 1990). The response to both these treatments occurs through calcium entry into the cells, either through the NMDA receptor/channel complex or through voltage-dependent L-type calcium channels (Gallo et al., 1987; Moran and Patel, 1989; 
Cambray-Deakin and Burgoyne, 1992). Thus, changes in the concentration of intracellular calcium may be an important mechanism regulating cerebellar cell development and differentiation in vivo. We have observed that the increase in Cns-1 expression, in response to NMDA, is also dependent on calcium. Both extracellular and intracellular chelation of calcium reduced the increase in Cns-I expression in response to NMDA (Fig. 10). This experiment might suggest that calcium entry through the NMDA channel is responsible for the increase in the level of $\mathrm{Cns}-1$ expression. However, we can't rule out that calcium released from intracellular stores is also involved in this response. We have tested the effect of several other agents on Cns- 1 expression in these postnatal cerebellar cultures. Only NMDA and high concentrations of $\mathrm{KCl}(40 \mathrm{~mm})$ resulted in an increase in Cns- 1 transcript levels. Treatment of cells with GABA, somatostatin, or basic fibroblast growth factor did not affect the level of Cns-I RNA (Fig. 10) though cultured granule cells express functional receptors for all three of these ligands (Hatten et al., 1988; Bovolin et al., 1992; Gonzalez et al., 1992). An increase in the level of Cns- $1 \mathrm{mRNA}$ in response to $40 \mathrm{~mm} \mathrm{KCl}$ is not blocked by the addition of APV (X. Lin, unpublished observation). This observation suggests that the response to $\mathrm{KCl}$ is not do to $\mathrm{K}^{+}$-induced release of endogenous glutamate activating NMDA receptors. Thus, this response appears specific to NMDA receptor activation and $\mathrm{KCl}$ depolarization, both of which allow calcium to enter cells. Changes in $C n s-1$ expression may be part of the mechanism by which Calcium regulates differentiation and development of cultured cerebellar cells.

Both NMDA receptor activation and changes in intracellular calcium can have important effects on development and plasticity in the CNS. Spontaneously active NMDA receptors are present in the early developing CNS (Blanton et al., 1990; Lo lurco et al., 1991). Activity-dependent development of certain CNS neurons requires NMDA receptor activation (Kleinschmidt et al., 1987; Scherer and Udin, 1989; Cline and Constantine-Paton, 1990; Kalb and Hockfield, 1990; Simon et al., 1992). Changes in the intracellular concentration of calcium have been shown to play an important role in regulating neuronal differentiation and neuronal growth cone behavior (Mattson et al., 1988; Holliday and Spitzer, 1990; Kater and Mills, 1991). The observation that Cns- $\mathrm{I}$ is expressed throughout the CNS suggests that NMDA receptor activation or changes in the intracellular calcium concentration may also modify its expression in other CNS cells. Thus, Cns- 1 could have several roles in regulating development and plasticity in the CNS.

\section{References}

Adler R, Hatlee M (1989) Plasticity and differentiation of embryonic retinal cells after terminal mitosis. Science 243:391-393.

Akam M (1987) The molecular basis for metameric pattern in the Drosophila embryo. Development 101:1-22.

Balázs R, Hack N, Jorgensen OS (1988a) Stimulation of the $N$-methylD-aspartate receptor has a trophic effect on differentiating cerebellar granule cells. Neurosci Lett 87:80-86.

Balázs R, Jorgensen OS, Hack N (1988b) $N$-methyl-D-aspartate promotes the survival of cerebellar granule cell in culture. Neuroscience 27:437-451.

Blanton MG, Lo Turco JJ, Kriegstein AR (1990) Endogenous neurotransmitter activates $N$-methyl-D-aspartate receptors on differentiating neurons in embryonic cortex. Proc Natl Acad Sci USA 87: $8027-8030$

Bovolin P, Santi MR, Puia G, Costa E, Grayson D (1992) Expression pattern of $\gamma$-aminobutyric acid typc A receptor subunit mRNAs in primary cultures of granule neurons and astrocytes from neonatal rat cerebella. Proc Natl Acad Sci USA 89:9344-9348.
Bowe MA, Nadler JV (1990) Developmental increase in the sensitivity to magnesium of NMDA receptors on CA1 hippocampal pyramidal cells. Dev Brain Res 56:55-61

Cambray-Deakin MA, Burgoyne RD (1992) Intracellular $\mathrm{Ca}^{2+}$ and $N$-methyl-D-aspartate-stimulated neuritogenesis in rat cerebellar granule cell culture. Dev Brain Res 66:25-32

Chomczynski P, Sacchi N (1987) Single step method of RNA isolation by acid guanidinium thiocyanate-phenol-chloroform extraction. Anal Biochem 162:156.

Chou PY, Fasman GD (1978) Empirical predictions of protein conformation. Ann Rev Biochem 47:251-276.

Cline HT (1991) Activity-dependent plasticity in the visual system of frogs and fish. Trends Neurosci 14:104-111.

Cline HT, Constantine-Paton M (1990) NMDA receptor agonist and antagonists alter retinal ganglion cell arbor structure in the developing frog retinotectal projection. J Neurosci 10:1197-1216.

Cole AJ, Saffen DW, Baraban JM (1989) Rapid increase of an immediate early gene messenger RNA in hippocampal neurons by synaptic NMDA receptor activation. Nature 340:474-476.

Cox JA, Felder CC, Henneberry RC. (1990) Differential expression of excitatory amino acid receptor subtypes in cultured cerebellar neurons. Neuron 4:941-947.

Cull-Candy SG, Ogden DC (1985) Ion channels activated by L-glutamate and GABA in cultured cerebellar neurons of the rat. Proc $\mathrm{R}$ Soc Lond [Biol] 224:367-373.

D'Angelo E, Rossi P, Garthwaite J (1990) Dual-component NMDA receptor currents at a single central synapse. Nature 346:467-470.

Davis CA, Joyner AL (1988) Expression patterns of the homeoboxcontaining genes En- 1 and En- 2 and the proto-oncogene Int- 1 diverge during mouse development. Genes Dev 2:1736-1744.

Davis CA, Noble-Topham SE, Rossant J, Joyner AL (1988) Expression of the homeobox-containing gene En-2 delineates a specific region of the developing mouse brain. Genes Dev 2:361-371.

Doe CQ, Hiromi Y, Gehring WI, Goodman CS (1988a) Expression and function of the segmentation gene Fushi Tarazu during Drosophila neurogenesis. Science 239:170-175.

Doe CQ, Smouse D, Goodman CS (1988b) Control of neuronal fate by the Drosophila segmentation gene even-skipped. Nature 333:376378.

Driever W, Nüsslein-Volhard C (1989) The bicoid protein is a positive regulator of hunchback transcription in the early Drosophila embryo. Nature 337:138-143.

Finney M, Ruvkun G, Horvitz RH (1988) The C. elegans ceil lineage and differentiation gene $u n c-86$ encodes a protein with a homeodomain and extended similarity to transcription factors. Cell 55:757769

Gallo V, Ciotti MT, Coletti A, Aloisi F, Levi G (1982) Selective release of glutamate from cerebellar granule cells differentiating in culture. Proc Natl Acad Sci USA 79:7919-7923.

Gallo V, Kingsbury A, Balázs R, Jorgensen OS (1987) The role of depolarization in the survival and differentiation of cerebellar granule cells in culture. J Neurosci 7:2203-2213.

Gao W, Heintz N, Hatten ME (1991) Cerebellar granule cell neurogenesis is regulated by cell-cell interactions in vitro. Neuron 6:841854.

Gonzalez B, Leroux P, Lamacz M, Bodenant C, Balázs R, Vaudry H (1992) Somatostatin receptors are expressed by immature cerebellar granule cells: evidence for a direct inhibitory effect of somatostatin on neuroblast activity. Proc Natl Acad Sci USA 89:9627-9631.

Goulding MD, Chalepakis G, Deutsch U, Erselius JR, Gruss P (1991) Pax-3, a novel murine DNA binding protein expressed during early neurogenesis. EMBO J 10:1135-1147.

Greenberg ME, Ziff EB (1984) Stimulation of $3 T 3$ cells induces transcription of the c-fos proto-oncogene. Nature 311:433-438.

Groudine M, Peretz M, Weintraub H (1981) Transcriptional regulation of hemoglobin switching in chicken embryos. Mol Cell Biol 3:281288.

Hatten ME, Lynch M, Rydel RE, Sanchez J, Joseph-Silverstein J, Moscatelli D, Rifkin DB (1988) In vitro neurite extension by granule cells is dependent upon astroglial derived fibroblast growth factor. Dev Biol 125:280-289.

He X, Rosenfeld MG (1991) Mechanisms of complex transcriptional regulation: implications for brain development. Neuron 7:183-196.

He X, Treacy MN, Simmons DM, Ingraham HA, Swanson LW, Rosenfeld MG (1989) Expression of a large family of POU-domain 
regulatory genes in mammalian brain development. Nature 340:3542 .

HenikoffS (1984) Unidirectional digestion with exonuclease III creates targeted breakpoints for DNA sequencing. Gene 28:351.

Holliday J, Spitzer NC (1990) Spontaneous calcium influx and its roles in differentiation of spinal neurons in culture. Dev Biol 141:1323.

Iacovitti L, Evinger MJ, Joh TH, Reis DJ (1989) A muscle-derived factor(s) induces expression of a catecholamine phenotype neurons in neurons of cultured rat cerebral cortex. J Neurosci 9:3529-3537.

Ingham PW (1988) The molecular genetics of embryonic pattern formation in Drosophila. Nature 335:25-34.

Ingraham HA, Flynn SE, Voss JW, Albert VR, Kapiloff MS, Wilson L, Rosenfeld MG (1990) The POU-specific domain of pit- 1 is essential for sequence-specific, high-affinity DN $\Lambda$ binding and DNA-dependent pit-1-pit-1 interactions. Cell 61:1021-1033.

Johnson JW, Ascher P (1987) Glycine potentiates the NMDA response in cultured brain neurons. Nature 325:529-531.

Kalb RG, Hockfield S (1990) Induction of a neuronal proteoglycan by the NMDA receptor in the developing spinal cord. Science 250 294-296.

Kalb RG, Lidow MS, Halsted MJ, Hockfield S (1992) N-methyl-Daspartate receptors are transiently expressed in the developing spinal cord ventral horn. Proc Natl Acad Sci USA 89:8502-8506.

Kater SB, Mills LR (1991) Regulation of growth cone behavior by calcium. J Neurosci 11:891-899.

Kaufman TC, Lewis R, Wakimoto B (1980) Cytogenetic analysis of chromosome 3 in Drosophila melanogaster: the homeotic gene complex in polytene chromosomal interval 84A, B. Genetics 94:1 15-133.

Kessel M, Gruss P (1990) Murine developmental control genes. Science 249:374-379.

Kessler JA (1986) Differential regulation of cholinergic and peptidergic development in the rat striatum in culture. Dev Biol 113:77-89.

Kingsbury AE, Gallo V, Balázs R (1989) Culture of rat cerbellar interneurons in chemically defined medium. In: A dissection and tissue culture manual of the nervous system (Shahar A, de Vellis J, Vernadakis A, Haber B, eds), pp 207-210 New York: Liss.

Kleinschmidt A, Bear MF, Singer W (1987) Blockade of NMDA receptors disrupts experience-dependent plasticity of kitten striate cortex. Science 238:355-358

Komuro H, Rakic P (1992) Modulation of neuronal migration by NMDA receptors. Science 260:95-97.

Kozak M (1986) Point mutations define a sequence flanking the AUG initiator codon that modulates translation by eukaryotic ribosomes. Cell 44:283-292.

Kozak M (1991) Structural features in eukaryotic mRNAs that modulate the initiation of translation. J Biol Chem 266:19867-19870.

Le Moine C, Young WS III (1992) RHS2, a POU domain-containing gene, and its expression in developing and adult rat. Proc Natl Acad Sci USA 89:3285-3289.

Lewis EB (1963) Genes and developmental pathways. Am Zool 3:3356.

Lipton SA, Kater SB (1989) Neurotransmitter regulation of neuronal nutgrowth, plasticity and survival. Trends Neurosci 12:265-270.

Lo Turco JL, Blanton MG, Kriegstein AR (1991) Initial expression and endogenous activation of NMDA channels in early neocortical development. J Neurosci 1 1:792 799.

Luskin MB, Pearlman AL, Sanes JR (1988) Cell lineage in the cerebral cortex of the mouse studied in vivo and in vitro with a recombinant retrovirus. Neuron 1:635-647.

Mattson M, Dou P, Kater SB (1988) Outgrowth-regulation action of glutamate in isolated hippocampal pyramidal neurons. $\mathbf{J}$ Neurosci 8:2087-2100.

Mayer ML, Westbrook GL, Guthrie PB (1984) Voltage-dependent block by $\mathrm{Mg}^{2+}$ of NMDA responses in spinal cord neurons. Nature 309:261-263.

McConnell SK, Kaznowski CE (1991) Cell cycle dependence of laminar determination in developing neocortex. Science 254:282-285.

Messer A (1989) Cell-specific enrichment of primary monolayer culture of postnatal rodent cerebellum. In: A dissection and tissue culture manual of the nervous system (Shahar A, de Vellis J, Vernadakis A, Haber B, eds), pp 195-197. New York: Liss.

Monuki ES, Weinmaster G, Kuhn R, Lemke G (1989) SCIP: a glial POU domain gene regulated by cyclic AMP. Neuron 3:783-793.

Moran J, Patel AJ (1989) Stimulation of the $N$-methyl-D-aspartate receptor promotes the biochemical differentiation of cerbellar granule neurons and not astrocytes. Brain Res 486:15-25

Morgan JI, Curran T (1991) Stimulus-transcription coupling in the nervous system: involvement of the inducible proto-oncogenes fos and jun. Annu Rev Neurosci 14:421-451

Morrisett RA, Mott DD, Lewis DV, Wilson WA, Swartzwelder HS (1990) Reduced sensitivity of the $N$-methyl-D-aspartate component of synaptic transmission to magnesium in hippocampal slices from immature rats. Dev Brain Res 56:257-262.

Odenwald WF, Taylor CF, Palmer-Hill FJ, Friedrich V, Tani M, Lazzarini RA (1987) Expression of a homeodomain protein in noncontact-inhibited cultured cells and postmitotic neurons. Genes Dev $1: 482-496$.

Pearce IA, Cambray-Deakin MA, Burgoyne RD (1987) Glutamate acting on NMDA reccptors stimulatcs ncurite outgrowth from cerebellar granule cells. FEBS Lett 223:143-147.

Porteus MH, Bulfone A, Ciaranello RD, Rubenstein JLR (1991) Isolation and characterization of a novel cDNA encoding a homeodomain that is developmentally regulated in the ventral forebrain. Neuron 7:221-229.

Price M, Lazzaro D, Pohl T, Mattei M-G, Rüther U, Olivo J-C, Duboule D, Di Lauro R (1992) Regional expression of the homeobox gene Nkx-2.2 in the developing mammalian forebrain. Neuron 8:241-255.

Rosenfeld MG (1991) POU-domain transcription factors: pou-er-ful developmental regulators. Gene Dev 5:897-907.

Ruvkun G, Finney M (1991) Regulation of transcription and cell identity by domain proteins. Cell 64:475-478.

Sambrook J, Fritsch EF, Maniatis T (1989) Molecular cloning, 2d ed Cold Spring Harbor, NY: Cold Spring Harbor Laboratory.

Sanger F, Nicklen S, Coulson AR (1977) DNA sequencing with chain terminating inhibitors. Proc Natl Acad Sci USA 74:5463-5467.

Scherer WJ, Udin SB (1989) $N$-methyl-D-aspartate antagonists prevent interactions of binocular maps in Xenopus tectum. J Neurosci 9:3837-3843.

Sciancalepore M, Forti L, Moran O (1989) Changes of $N$-methyl-Daspartate activated channels of cerebellar granule cells with days in culture. Biochem Biophys Res Commun 165:481-487.

Scott MP, Carroll SB (1987) The segmentation and homeotic gene network in early Drosophila development. Cell 51:689-698.

Simon DK, Prusky GT, O'Leary DM, Constantine-Paton M (1992) $N$-methyl-D-aspartate receptor antagonists disrupt the formation of a mammalian neural map. Proc Natl Acad Sci USA 89:10593-10597.

Struhl G, Struhl K, Macdonald PM (1989) The gradient morphogen bicoid is a concentration-dependent transcriptional activator. Cell 57 1259-1273.

Sturm RA, Herr W (1988) The POU domain is a bipartite DNAbinding structure. Nature 336:601-604.

Szekely AM, Barbaccia ML, Alho H, Costa E (1989) In primary cultures of cerebellar granule cells the activation of $N$-methyl-D-aspartate-sensitive glutamate receptors induces c-fos mRNA expression. Mol Pharm 35:401-408.

Tanaka M, Herr W (1990) Differential transcriptional activation by Oct-1 and Oct-2: interdependent activation domains induce Oct-2 phosphorylation. Cell 60:375-386.

Theill LE, Castrillo J-L, Wu D, Karin M (1989) Dissection of functional domains of the pituitary-specific transcription factor GHF-1. Nature 342:945-948.

Trenkner E (1991) Cerebellar cells in culture. In: Culturing nerve cells (Banker G, Goslin K, eds), pp 283-307. Cambridge, MA: MIT Press.

Trenkner E, Sidman RL (1977) Histogenesis of mouse cerebellum in microwell culture: cell reaggregation and migration, fiber and synapse formation. J Cell Biol 75:915-940.

Turner DL, Cepko CL (1987) A common progenitor for neurons and glia persists in rat retina late in development. Nature 328:131-136.

Van Vliet BJ, Sebben M, Dumuis A, Gabrion J, Bockaert J, Pin J-P (1989) Endogenous amino acid release from cultured cerebellar neuronal cells: effect of tetanus toxin on glutamate release. J Neurochem 52:1229-1239.

Walsh C, Cepko CL (1992) Widespread dispersion of neuronal clones across functional regions of the cerebral cortex. Science 255:434-440.

Way JC, Chalfie M (1989) The mec-3 gene of Caenorhabditis elegans requires its own product for maintained expression and is expressed in three neuronal cell types. Gene Dev 3:1823-1833.

Wetts R, Fraser SE (1988) Multipotent precursors can give rise to all major cell types of the frog retina. Science 239:1142-1145. 